\title{
Pneumatologia w eklezjologii Konstytucji Lumen gentium Soboru Watykańskiego II z perspektywy teologii Yves'a Congara
}

Dla Yves'a Congara opatrznościowy okazał się marzec 1963 roku, gdy jako teolog został poproszony o współpracę w redakcji jednej z najważniejszych konstytucji soborowych, Konstytucji dogmatycznej o Kościele Lumen gentium ${ }^{2}$. W tym studium pragnę przeanalizować pneumatologię zastosowaną w eklezjologii tego dokumentu, podejmując się tego zadania z perspektywy myśli francuskiego teologa. Nie chcę odnosić się do analizy całej pneumatologii Y. Congara, lecz spojrzeć z perspektywy jego refleksji na zawiłości pneumatologii zawartej w soborowej Konstytucji dogmatycznej o Kościele. Zainteresowanie teologiczne Congara tą kwestią sięgało okresu przedsoborowego. Sobór wpłynął na rozwój owego poszukiwania. Po Soborze dociekanie to stało się jego życiowym programem badawczym. Teologia francuskiego badacza świadczy o wystarczającej kompetencji, aby z jej perspektywy podjąć się studium eklezjologii soborowej.

Analiza prowadzona $\mathrm{w}$ tym artykule skupi się na dwóch kwestiach badawczych. Pierwszą będzie krótkie nakreślenie odpowiedzi Congara na zarzuty niektórych soborowych obserwatorów o braku zastosowania pneumatologii w refleksji nad Kościołem przez twórców Soboru Watykańskiego II. Zostanie wyjaśniona replika Congara na zarzuty o chrystomonizm, który miał wykluczać trynitarne ujęcie całej refleksji. Drugą kwestią badawczą tego studium będzie wykazanie teologicznej korelacji refleksji na temat pneumatologii w eklezjologii u Yves'a Congara z tekstem Lumen gentium. W centrum analizy znajdzie się

${ }^{1}$ Ksiądz dr Artur Antoni Kasprzak — kapłan diecezji kaliskiej, wykładowca na Wydziale Teologicznym Uniwersytetu Kardynała Stefana Wyszyńskiego w Warszawie (artur.kasprzak@wanadoo.fr). ORCID: 0000-0001-9715-9357.

${ }^{2}$ G. Philips, K. Schelkens, Carnets conciliaires de Mgr Gérard Philips secrétaire adjoint de la Commission doctrinale, (Instrumenta Theologica 29), Leuven 2006, s. 94. Cf. FConc Suenens nr 754, s. 4, list A. Prignona do kard. Suenensa 8-10 marca 1963. 
artykuł Yves'a Congara Aktualność pneumatologii, w którym autor przedstawia pięć tez teologicznych, temat Ducha Świętego i Kościoła, odwołując się często do Soboru Watykańskiego II.

$Z$ racji obszerności i różnorodności problematyki nie jest tutaj możliwe prześledzenie całej koncepcji pneumatologicznej eklezjologii u Yves'a Congara ${ }^{3}$. Niniejsze rozważanie ogranicza się do treści refleksji Congara napisanej w kontekście Soboru Watykańskiego II i jeszcze przed wydaniem jego trylogii o Duchu Świętym na przełomie lat siedemdziesiątych i osiemdziesiątych XX wieku4.

\section{Odpowiedź Y. Congara wobec zarzutu obserwatorów soborowych chrystomonizmu w refleksji Vaticanum Secundum}

Yves Congar nie podejmuje szczególnej walki wobec krytyków Soboru w wyjaśnianiu pneumatologii w eklezjologii zawartej w Konstytucji dogmatycznej o Kościele. Jego dialog z polemistami, podjęty zresztą dopiero kilka lat po Soborze, wyjaśnia jedynie zasadniczą bezpodstawność argumentów krytyki, wysuwanych przez niektórych obserwatorów Soboru Watykańskiego II $^{5}$, zwłaszcza Nikosa

${ }^{3}$ Badania nad kwestią pneumatologii u Congara są już zaproponowane. Zob. najpierw analizę samego autora: Y. Congar, La Parole et le Souffle, (Jésus et Jésus-Christ, n²0), Paris 2010. Zob. prace doktorskie (przykłady): F.M. Humann, La relation de l'Esprit au Christ: Une relecture d'Yves Congar, (CFi), Paris 2010. F.R. Milciades, La eclesiologia pneumatologica de Yves Congar en los escritos del periodo post-conciliar, Roma 2013. Zob. również opracowania i studia (przykłady): R. Chéno, Le Père Congar, découvreur de sources nouvelles [w:] Y. Congar, La Parole et le Souffle, Paris 2010, s. 211-221; J. Rigal, Ecclésiologie de la communion. Son évolution historique et ses fondements, (CFi), Paris 2000, s. 157-161. E.T. Groppe, Yves Congar's theology of the Holy Spirit, Oxford-New York 2004.

${ }^{4}$ Por.: Y. Congar, Je crois en l'Esprit Saint, 1: L'Esprit Saint dans l',économie”: révélation et expérience de l'Esprit, Paris 1979; tenże, Je crois en l'Esprit Saint, 2: „Il est Seigneur et Il donne la vie", Paris 1979; tenże, Je crois en l'Esprit Saint. 3. Le Fleuve de Vie (Ap 22,1) coule en Orient et en Occident, Paris 1985. W tłumaczeniu na j. polski: tenże, Wierzę w Ducha Świętego, t. I: Duch święty w ,ekonomii”. Objawienie i doświadczenie Ducha, tłum. A. Paygert, Warszawa 1997; tenże, Wierzę w Ducha Świętego, t. II: „Panem jest Duch i daje życie” (2 Kor 3,17), tłum. L. Rutkowska, Warszawa 1995; tenże, Wierzę w Ducha Świętego, t. III: Rzeka życia plynie na Wschodzie i na Zachodzie (Ap 22,1), thum. L. Rutkowska, Warszawa 1996.

${ }^{5}$ Krytyka wizji Kościoła, sugerująca jej chrystomonizm na Soborze Watykańskim II, została sformułowana zwłaszcza ze strony teologów prawosławnych. Ich zdaniem potrzebne było zaakcentowanie roli Ducha Świętego jako tajemnicy. Kwestia ich zarzutu rozciągała się także poza Sobór Watykański II. Powracał cały czas w dyskusji temat filioque, czyli ich zdaniem błędne twierdzenie o pochodzeniu Ducha Świętego „również od Syna”. Jak pisze Congar: „[p]rawosławni uważają konstrukcję łacińską za zbyt racjonalistyczną. Sądzą również, że uzależnia ona Ducha od Słowa, od Chrystusa; dlatego też Zachód popadł w to, co nazywają oni “chrystomonizmem'” (tenże, Duch człowieka, Duch Boga, thum. A. Foltyńska, Warszawa 1996, s. 50). Por. M. Jagielski, L'Église dans le temps. Yves Congar: la quête d'un réalisme ecclésiologique, Paris 2015, s. 390. (Por. źródła w dwóch kolejnych przypisach). 
A. Nissiotisa ${ }^{6}$. Na jego odpowiedź składają się zasadniczo dwa artykuły: Pneumatologia czy ,,christomonizm” w tradycji łacińskiej? z 1970 roku oraz Implikacje chrystologiczne i pneumatologiczne eklezjologii Soboru Watykańskiego II, którego tekst w swojej genezie był wykładem wygłoszonym w 1980 roku podczas kolokwium w Bolonii ${ }^{7}$.

Wbrew zarzutom o chrystomonizm eklezjologii soborowej badania Congara potwierdzają realne zastosowanie pneumatologicznego ujęcia Kościoła na Soborze. W powierzchownej analizie teolog wymienia znaczące formuły teologii trynitarnej zastosowane $\mathrm{w}$ różnych tekstach soborowych:

Dziewięć razy powraca idea, która należy do istoty myśli Ojców [Kościoła] i która jest duszą całej liturgii: [Bogu] Ojcu, przez Syna i Ducha [KK 4, 28, 51; KO 2; KL 6; DP 6; DFK 8; DM 7; DE 15]. Dwa razy Kościół jest określony w sposób trynitarny jako lud Boży, Ciało Chrystusa, Świątynia Ducha Świętego: KK 17; DP 1. Przynajmniej jeden raz pada wyraźnie, że „Największym wzorem i zasadą tego misterium [Kościoła] jest jedność w Trójcy Osób jednego Boga Ojca i Syna i Ducha Świętego" (DE 2/6)

W tej pierwszej analizie Congar podsumowuje: „[s]ens tego wszystkiego jest jasny: wobec wizji zasadniczo jurydycznej i przez fakt dominanty czysto chrystologicznej zamieniono ją na wizję Kościoła jako komunii osób i komunii Ko-

${ }^{6}$ Zob. m.in.: N.A. Nissiotis, Pneumatologie orthodoxe [w:] Le Saint-Esprit (ouvr. collectif), Genève 1963, s. 85-106; tenże, Is the Vatican Council Really Ecumenical?, „The Ecumenical Review” 16 (07/1964) 4, s. 357-377, tu: s. 365; tenże, Report on the Second Vatican Council, „The Ecumenical Review" 18 (04/1966) 2, s. 190-206, tu: s. 193n; tenże, The Main Ecclesiological Problem of the Second Vatican Council and the Position of the Non-Roman Churches Facing It, „Journal of Ecumenical Studies”, 2 (01/1965) 1, s. 31-62, tu: s. 48.

7 Zob.: Y. Congar, Pneumatologie ou «Christomonisme» dans la tradition latine? [w:] Ecclesia a Spiritu Sancto edocta. Mélanges théologiques. Hommages à Mgr Gérard Philips, (Bibliotheca Ephemeridum theologicarum Lovaniensium XXVII), J. Duculot, Gembloux 1970, s. 41-63. Zob. tenże, Les implications christologiques et pneumatologiques de l'ecclésiologie de Vatican II [w:] Les Églises après Vatican II. Dynamisme et prospective. Actes du Colloque international de Bologne - 1980, (TH, n 61), éd. G. Alberigo, Paris, 1982, s. 117-130. Ten sam tekst w: tenże, Les implications christologiques et pneumatologiques de l'ecclésiologie de Vatican II [w:] tenże, Le Concile de Vatican II. Son Église. Peuple de Dieu et Corps du Christ, (TH, n 71), Paris 1984, s. $163-176$.

8 Tekst jest tłumaczeniem własnym. Uwaga dotyczy wszystkich pozostałych tekstów tłumaczonych, podanych również w wersji oryginalnej. „Neuf fois revient l'idée qui est l'âme de la pensée des Pères et l'âme de la liturgie: au Père, par le Fils, dans l'Esprit [LG, 4; 28, 51; DV, 2; SC, 6; OT, 8; AG, 7/3; UR, 15/1]. Deux fois l'Église est désignée de façon trinitaire comme Peuple de Dieu, Corps du Christ, Temple de l'Esprit-Saint: LG 17; PO, 1. Une fois au moins il est dit expressément que «de ce mystère (de l'Église), le modèle suprême et le principe est dans la trinité des Personnes l'unité d'un seul Dieu Père, et Fils, en l'Esprit-Saint» (UR, 2/6)". Y. Congar, Les implications..., $\left(\mathrm{TH}, \mathrm{n}^{\circ} 71\right)$, s. 175-176. 
ściołów lokalnych, w perspektywie trynitarnej"9. Congar stwierdza dosadnie: „[m]ówienie o 'chrystomonizmie' na Soborze Watykańskim II, zwłaszcza wobec Lumen gentium, lub mówienie, że 'posypano' tekst Duchem Świętym, suponowałoby, że nie przeczytano tekstów lub że je przeczytano z niewłaściwym spojrzeniem"10.

W konkluzjach swoich badań teolog przyznaje, że choć nie zauważa się problemu chrystomonizmu, to jednak soborowa perspektywa opisująca Kościół skupiła się na centralizującej roli Chrystusa. Pneumatologiczne ujęcie Kościoła zostało jednak zachowane, aczkolwiek pojawia się ono w silnej perspektywie chrystologii ${ }^{11}$. Congar wyjaśnia, że powodem takiego podejścia teologicznego przez Sobór była sama tradycja łacińska traktująca Kościół przede wszystkim jako strukturę ${ }^{12}$. Skoncentrowanie refleksji Lumen gentium na chrystologii nie wypierało jednak pneumatologii. Congar odwołuje się w swojej argumentacji do słynnego przemówienia Pawła VI z 29 września 1963 roku, gdy sam papież na otwarcie drugiej sesji Soboru uznał za właściwe owo centralne i jednocześnie uniwersalne znaczenie chrystologii dla zrozumienia Kościoła:

Jest tylko jedna odpowiedź do przekazania: ...Chrystus. Chrystus: nasza zasada; Chrystus: naszą drogą i naszym przewodnikiem; Chrystus: naszą nadzieją i naszym końcem [...]. Jesteśmy wszyscy jego wybranymi, jego uczniami, jego apostołami, jego świadkami, jego posługującymi, jego przedstawicielami i, ze wszystkimi innymi wiernymi, jego żywymi członkami, zjednoczonymi w tym olbrzymim i jedynym Ciele mistycznym, które On, przez środki wiary i sakramenty, jest w trakcie tworzenia przez wszystkie pokolenia ludzkie ${ }^{13}$.

9 „Le sens de tout cela est clair: à une vision principalement juridique, et par le fait à dominante purement christologique, on a substitué une vision de l'Église comme communion de personnes et communion d'Églises locales, dans une perspective trinitaire”. Tamże, s. 176.

10 „Parler de 'christomonisme' pour Vatican II, singulièrement pour Lumen Gentium, ou dire qu'on a seulement 'saupoudré' le texte de Saint-Esprit, ferait supposer qu'on n'a pas lu les textes ou qu'on les a lus avec un regard prévenu”. Tamże.

11 Yves Congar w wywiadzie z Jeanem Puyo powiedział: „[m]ówi się często, że Zachód nie posiada teologii Ducha Świętego. Zarzut ten jest dowodem ignorancji. Pod tym względem Zachód można porównać ze Wschodem. Ściśle jednak ujmując, 'pneumatologia' jest czymś więcej aniżeli uznanie trzeciej Osoby Trójcy Świętej. Teologia ta mówi o wpływie Ducha Świętego na naszą wizję Kościoła. Oznacza to, że wszyscy żyjący chrześcijanie mają Ducha" (tenże, Jean Puyo interroge le père Congar. "Une vie pour la vérité», Paris 1975, s. 196 [cyt. z polskiego wyd.: tenże, Życie dla prawdy. Jean Puyo rozmawia z ojcem Y. Congarem, tłum. A. Paygert, Warszawa 1975, s. 167].

12 Por. tenże, Pneumatologie...

13 Thumaczenie własne $\mathrm{z}$ tekstu thumaczenia francuskiego. „Il n’y a qu'une réponse à leur donner...: le Christ. Le Christ: notre principe; le Christ: notre voie et notre guide; le Christ: notre espérance et notre fin [...] Nous sommes ses élus, ses disciples, ses apôtres, ses témoins, ses ministres, ses représentants et, avec tous les autres fidèles, ses membres vivants, unis dans cet immense et unique Corps mystique, que Lui, par le moyen de la foi et des sacrements, est en train de se constituer au cours des générations humaines". Paweł VI, Documentation Catholique (1963), s. 1349-1340 za: Y. Congar, Les implications ..., (TH, n 71), s. 166-167. 
Rzeczywiście osią całego wyjaśnienia Kościoła w Konstytucji Lumen gentium jest sam Chrystus ${ }^{14}$. Tak właśnie została zredagowana pierwsza część dokumentu (I i II rozdział). Reasumując, uzasadnione jest usytuowanie chrystologii w samym centrum całej Konstytucji o Kościele, gdyż mówienie o Chrystusie nie wyklucza mówienia o Duchu Świętym. Oto jak Congar dostrzega tę perspektywę w samym schemacie kluczowych wyrażeń, które użyte zostały sukcesywnie w I rozdziale dokumentu soborowego:

Pierwsze słowa Konstytucji o Kościele dokładnie odpowiadają takiej wizji. 11 września 1962 roku Jan XXIII powiedział o Kościele jako „Lumen gentium”, odwołując się następnie do „lumen Christi" z wigilii paschalnej. Sobór uczynił z tych słów tytuł swojej Konstytucji dogmatycznej, ale odnosząc je do Chrystusa, operując łacińskim wyrażeniem pełnym kontrastów „Lumen gentium cum sit Christus” [...] Następnie mamy od numeru 3. echo tego samego [zamysłu] ,[o] mnes homines ad hanc vocantur unionem cum Christo, qui est lux mundi, a quo procedimus, per quem vivimus, ad quem tendimus” i w numerze 8. „Unicus Mediator Christus”, ideę wyjaśnioną w szczegółach w numerze 60, à propos dobrze znanego tytułu maryjnego ${ }^{15}$.

Zdaniem Congara pierwsze bezpośrednie pneumatologiczne rozumienie, zawierające się w chrystologii soborowej, odnosi się do „Chrystusa działającego w Kościele”. Francuskiemu teologowi chodziło o znaczenie wyrażenia „Chrystusa chwalebnego", natomiast w rozumieniu Soboru odzwierciedlało się ono w koncepcji sakramentalnej Kościoła. Sam Kościół przedstawiony został przez Sobór jako sakrament podstawowy i globalny. W numerze 48. Konstytucji Lumen gentium zaznacza się:

Chrystus wywyższony nad ziemię przyciągnął wszystkich do siebie (por. J 12,32 gr.); powstawszy z martwych (por. Rz 6,9), zesłał na uczniów swojego Ducha Ożywiciela i przez Niego ustanowił swoje Ciało, którym jest Kościół, jako powszechny sakrament zbawienia. Siedząc po prawicy Ojca, działa ustawicznie w świecie $[\ldots]^{16}$.

Przedstawienie Kościoła jako sakramentu rozwinięte zostało na Soborze w kategorii „obecności”"17. Jak wyjaśnia dalej Congar, posługując się krótką ana-

${ }^{14} \mathrm{~W}$ momencie wypowiadania cytowanych tutaj słów przez papieża Pawła VI, pierwsza część Konstytucji Lumen gentium posiadała już swój pierwotny tekst redakcji, który koncentrował swoją uwagę na podejściu chrystologicznym, czyli tak samo, jak to podkreśla papież.

15 „Les premiers mots de la constitution sur l'Église répondent bien à cette vision. Jean XXIII avait, le 11 septembre 1962, parlé de l'Église comme 'lumen gentium', en se référant ensuite au 'lumen Christi' de la vigile Pascale. Le concile a fait de ces mots le titre de sa constitution dogmatique mais en le rapportant au Christ au prix d'une construction latine heurtée 'Lumen gentium cum sit Christus'... Puis c'est, dès le $\mathrm{n}^{\circ} 3$, cet écho: '[o]mnes homines ad hanc vocantur unionem cum Christo, qui est lux mundi, a quo procedimus, per quem vivimus, ad quem tendimus' et, au ${ }^{\circ} 8$ 'Unicus Mediator Christus', idée explicitée au n ${ }^{\circ} 60$ à propos du titre marial bien connu'. Y. Congar. Les implications..., $\left(\mathrm{TH}, \mathrm{n}^{\circ} 71\right)$, s. 167.

${ }^{16}$ Sobór Watykański II. Konstytucje, dekrety, deklaracje, Pallottinum, Poznań 2002, s. 150.

17 Y. Congar, Les implications ..., $\left(\mathrm{TH}, \mathrm{n}^{\circ} 71\right)$, s. 167. 
lizą różnych form owej obecności, w Konstytucji o Liturgii wyciąga się wniosek: „[tak więc] Chrystus jest obecny zawsze w swoim Kościele, zwłaszcza w czynnościach liturgicznych" (KL 7) ${ }^{18}$. Sobór wyraźnie skupił uwagę obecności Chrystusa na osobie biskupa czy kapłana zgodnie z zasadą in persona Christi (zob. KK 21). Jak przyznaje Congar, ową obecność wyjaśnia się według tradycji scholastycznej, w sposób dosyć indywidualistyczny. Powodem jest kwestia tożsamości kapłańskiej i zdefiniowanie jej w kontekście kontrreformacji i okresu odnowienia antyrewolucyjnego ${ }^{19}$. Jednakże ujęcie tej samej problematyki w wymiarze wspólnotowym jest jak najbardziej możliwe na płaszczyźnie tekstów soborowych. Wciąż jest tutaj potencjalność pneumatologicznej interpretacji obecności Chrystusa w Kościele. Sobór zdefiniował kapłana w stosunku do totalnego apostolatu i misji, za cenę nawet zbytniego pomniejszenia, zdaniem Congara, odniesienia do wertykalnej chrystologii ${ }^{20}$.

Pierwsze przełamanie chrystomonizmu przez Sobór zawiera się w opinii Congara w numerze 14. Lumen gentium, w którym pojawia się istota fundamentalnego zdefiniowania Kościoła. Sobór stwierdza w tym fragmencie: ,[i]1li plenne Ecclesiae societati incorporantur, qui Spiritum Christi habentes, integram eius ordinationem [...] accipiunt". Congar konkluduje znaczenie tych słów:

Tak oto Kościół-społeczeństwo czy społeczeństwo-Kościół nie może zostać zdefiniowany inaczej, jak tylko poprzez wprowadzenie w niego [obecności] Ducha Chrystusa. Jest to początek przekroczenia „chrystomonizmu”. To tylko początek. Będzie to kontynuowane. Instytucja Chrystusa, rzeczywistość Kościoła-społeczeństwa są w posłudze Ducha Chrystusa: „Jak bowiem przybrana natura ludzka służy Słowu Bożemu jako żywe narzędzie zbawienia nierozerwalnie z Nim zjednoczone, podobnie społeczny organizm Kościoła służy ożywiającemu go Duchowi Chrystusa ku wzrastaniu tego ciała (por. Ef 4,16)" (KK 16). [Instytucja] jest więc również dynamiczna, ,ad augmentum corporis"21.

18 Sobór Watykański II..., s. 50.

${ }^{19}$ Y. Congar, Les implications ..., $\left(\mathrm{TH}, \mathrm{n}^{\circ} 71\right)$, s. 167.

${ }^{20}$ Bardzo ciekawa uwaga, w której Congar zauważa, że takie odniesienie prezbiteratu, to znaczy wyłącznie do apostolatu i misji, sprzyjało interpretacji korzystnej dla ruchów dążących do udzielania święceń kobietom. Tymczasem życzeniem francuskiego teologa było podjęcie „wysiłku dla zintegrowania i stworzenia syntezy pomiędzy sakramentalnością chrystologiczną, podejmowaną stosunkowo indywidualistycznie przez scholastykę, a odniesieniem do wspólnoty z tym wszystkim, co zawiera w sobie wymiar pneumatologii, i w końcu sam wysiłek Soboru, tak bardzo wymowny w dwóch odniesieniach biblijnych, które nie były wcześniej wzięte pod uwagę: J 10,36 ([fragment o synostwie Bożym] cytowany cztery razy przez Sobór) i Rz 15,16 ([fragment o funkcji służebnej urzędu Chrystusa] cytowany również cztery razy)" (tamże, s. 168).

${ }^{21}$ „Ainsi l'Église-société ou la société-Église ne peut se définir qu'en incluant l'Esprit du Christ. C'est le début du dépassement d'un 'christomonisme'. Le début seulement. Cela va continuer. L'institution du Christ, les réalités de l'Église-société sont au service de l'Esprit du Christ: 'Tout comme, en effet, la nature assumée par le Verbe divin est à son service comme un organe vivant de salut qui lui est indissolublement uni, de même le tout social que constitue l'Église est au service de l'Esprit du Christ qui lui donne vie, en vue de la croissance du corps (cf. Ep 4,16)' (LG, 8). C'est donc aussi dynamique, 'ad augmentum corporis'”. Tamże, s. 169. 
Congar z całą dobitnością podkreśla tutaj ulubioną tezę swojej eklezjologii pneumatologicznej. Jeśli Duch Święty nie jest tworzacym (instituant) Kościół, co zakłada protestanckie ujęcie pneumatologii Kościoła (na przykład Leonardo Boff), to Duch Święty jest współ-tworzący (co-instituant) Kościół ${ }^{22}$. Kościół jest założony przez Chrystusa, ale pozostaje instytucją otwartą. Jak to wyjaśnia słusznie Yves Congar w wielu swoich opracowaniach posoborowych, pneumatologia w eklezjologii polega na odpowiednim przedstawieniu połączenia wymiaru misji Ducha Świętego z misją Słowa Wcielonego ${ }^{23}$.

Powyższe wykazanie — zdefiniowanie roli Ducha Świętego jako „współ-tworzącego" w Kościele — rzeczywiście osłabia argumenty krytyków o braku pneumatologii $\mathrm{w}$ tekstach soborowych. Wyrażenie bowiem właściwie wyjaśnia to, co świadomie podkreślili ojcowie Soboru Watykańskiego II, że „nie można stawiać w opozycji, ani nawet rozdzielać społeczeństwa hierarchicznego i Ciała mistycznego Chrystusa, zgromadzenia widzialnego i wspólnoty duchowej, Kościoła ziemskiego i Kościoła obdarowanego darami niebieskimi24". Jak pisze Congar: „,[p]od tymi trzema związkami terminologii nie powinno się rozumieć dwóch 'rzeczy' czy dwóch podmiotów, lecz «jedną skomplikowaną rzeczywistość, stworzoną z podwójnego elementu ludzkiego i boskiego»" ${ }^{25}$. Sobór przedstawił Kościół tak, jak zaproponował św. Paweł: jako zamieszkanie Ducha Świętego w Głowie (Szefie) i w członkach Ciała (por. KK 7). Duch Święty jest tutaj porównany tradycyjnie do duszy ciała, ale również do Kościoła, który jest Oblubienicą i Pléroma (pełnią), i który dąży do pełni w Bogu. Sobór, akcentując Kościół jako Ciało Chrystusa, a zatem chrystologię, przedstawia Chrystusa jako twórcę struktury Kościoła, w tym hierarchii (por. encyklika Mystici Corporis). Rozważanie nad Kościołem zachowuje jednak perspektywę pneumatologiczną.

${ }^{22}$ Zob. tamże.

${ }^{23}$ Oto znamienne słowa Yves'a Congara w tej kwestii: ,[1]e problème est toujours d'articuler l'œuvre du Verbe, révélateur du Père, et celle de l'Esprit. Ils sont co-instituants de l'Église. Mais l'Esprit n'a pas d'autonomie dans le substantiel de l'œuvre à laquelle le Verbe, Parole de Dieu et Fils incarné, doit donner forme" (tenże, L'Esprit co-instituant de l'Église. Les charismes principes structurants de l'Église? [w:] tenże, La Parole et le Souffle, Paris 2010, s. 129). Idea dwóch misji i opis ich działania w Kościele jest poruszona przez Piusa XII w encyklice Mystici Corporis w 1943 roku, zob.: Y. Congar, L'Esprit saint dans l'Église, „Lumière et Vie” 10 (1953), s. 51-74, tu: s. 57. Congar wyjaśnia podwójność misji działania Boga, analizując refleksję św. Tomasza z Akwinu (Suma Teologiczna, III, q. 8, a. 6), który mówi o dwóch modalnościach (modes), przez które Chrystus kontynuuje swoje formowanie i zarządzanie Kościołem: Y. Congar, La Tradition et la vie de l'Église, (Traditions chrétiennes), Paris $1984^{2}$, s. 45. Por. inne fragmenty o dwóch misjach Boga w Kościele i ich relacji między sobą: tenże, Wierzę..., t. II, s. 14-22; tenże, Pneumatologie..., s. $56-62$.

${ }^{24}$ Y. Congar, «Lumen Gentium» $n^{\circ}$ 7, L'Église, Corps Mystique du Christ vu au terme de huit siècles d'histoire de la théologie du Corps mystique [w:] tenże, Le Concile de Vatican II. Son Église. Peuple de Dieu et Corps du Christ, (TH, n 71), Paris 1984, s. 137-161, tu: s. 159.

${ }^{25}$ Tamże. 
W kolejnym numerze refleksji soborowej pojawia się wyraźne stwierdzenie, że chodzi o Kościół równocześnie widzialny i duchowy [niewidzialny]: „widzialne zgromadzenie jak i wspólnota duchowa, Kościół ziemski i Kościół bogaty w dobra niebieskie" (zob. KK 8) ${ }^{26}$.

Podwójne podejście w wyjaśnianiu zarazem hierarchicznego, jak i pneumatologicznego znaczenia Kościoła przez Sobór nie było wynikiem samej tylko dywagacji teologicznej. Ma ono swoje wytłumaczenie w zrozumieniu historii Soboru. Część ojców soborowych dostrzegała Kościół od strony jurydycznej i dogmatycznej, druga część, doceniając ten pierwszy wymiar, rozumiała Kościół jako wciąż odnawiany przez działanie Ducha Świętego, w myśl idei aggiornamento papieża Jana XXIII. Podwójne podejście do definicji Kościoła wypływało z dwóch szkół teologicznych ojców soborowych. Szkoła rzymska, cechująca się dowartościowaniem jurydycznego Kościoła, podkreślała widzialność Kościoła (akcentowała hierarchię i strukturę w Kościele). Szkoła bardziej otwarta na wymiar biblijny, patrystyczny i ekumeniczny — teolodzy ze środowisk Lovanium w Belgii, Fourvière z Lyonu, Saulchoir w Paryżu etc. — uczulała na wymiar niewidzialny Kościoła. Rezultat połączenia w tekście Lumen gentium dwóch wspomnianych podejść nie było sprzeniewierzeniem się pneumatologicznej wizji Kościoła. Jak podkreśla Congar w swoich pierwszych odpowiedziach na zarzuty krytyków po Soborze, Konstytucja Lumen gentium jest po prostu ujęciem całościowym, gdzie eklezjologia pneumatologiczna przedstawiona jest z perspektywy chrystologii. Chociaż z początku obrad Soboru było to mało oczywiste, priorytet argumentów w miarę rozwoju debaty soborowej przyznano drugiej szkole, bardziej otwartej na ontologię łaski niż na hierarchię 27 . Ostatecznie na Soborze doceniono bardziej misterium, element życia i ontologię łaski w Kościele. Congar napisał: „[Sobór Watykański II] spojrzał na Kościół jako na lud, wspólnotę łaski, będącą pod wpływem Trójcy Świętej poprzez misje Syna i Ducha"28. Jak podkreśla francuski dominikanin, Sobór świadomie nie związał się z ideą szkoły rzymskiej „Wcielenia kontynuowanego" (Incarnation continuée) ani ze schematem o hierarchii jako skutecznej przyczynie (cause efficiente) Billota, Journeta [...]: Chrystus - Apostołowie i ich sukcesorzy - Kościół ${ }^{29}$. Wykład soborowy o Kościele świadczy o właściwej neutralności wobec lokalnych szkół teologicznych czy prywatnych idei teologów dotyczących Kościoła. Niezaprzeczalną zasługę we właściwym sformułowaniu teologicznych niuansów, a także odpowiedniej proporcji pomiędzy wspomnianymi przed chwilą dwoma fundamentalnymi wymiarami wrażliwo-

${ }^{26}$ Sobór Watykański II..., s. 110.

27 Por. Y. Congar, Les implications... (TH, $\left.\mathrm{n}^{\circ} 71\right)$, s. 164.

${ }^{28}$, ,Le Concile Vatican II] voit l'Église comme un peuple, une communauté de grâce en dépendance de la Trinité par les missions du Fils et de l'Esprit". Tamże, 166.

${ }^{29}$ Por. tamże. 
ści eklezjologicznej, ma główny redaktor Lumen gentium, ks. prałat Gérard Philips. Cieszył się on niepodważalną zdolnością dyplomatycznej koncyliacji i zarazem otwarciem na odnowę w teologii.

\section{Pneumatologia w eklezjologii Y. Congara a proces zmian teologicznego rozumienia Kościoła od przedsoborowych ruchów odnowy teologii do Konstytucji Lumen gentium}

W 1973 roku Yves Congar opublikował artykuł zatytułowany Aktualność pneumatologii ${ }^{30}$, w którym przedstawia pięć tez syntetyzujących jego ówczesne przemyślenia dotyczące pneumatologicznych implikacji eklezjologii:

1. Kościół nie jest całkowicie zakończony.

2. Kościół cieszy się pełnią Ducha tylko w całości darów, uczynionych dla wszystkich członków.

3. Cechą Ducha jest subtelność — Duch aktualizuje dzieło Chrystusa jako wydarzenie, respektując każdą osobę.

4. W Kościele i teologii należy uznać działanie Ducha i nadać eklezjologii model trynitarny [...].

5. W linii stosunków między Chrystusem a Duchem Świętym trzeba usytuować wreszcie relację między tym, co jest dane i tym, co ma się wydarzyć... [...] Dana Chrystusa ma jeszcze wydarzyć się w historii w sposób jeszcze nieurzeczywistniony ${ }^{31}$.

Powyższe tezy nie są sformułowane na podstawie Konstytucji dogmatycznej o Kościele. W zamyśle Congara powstały one jako komentarz do eklezjologii pneumatologicznej, w celu wyjaśnienia zmian, jakie dokonały się już wcześniej w Kościele, albo zmian, które Kościół winien jeszcze wprowadzić do swojej teologii i praktyki duszpasterskiej. Pneumatologia eklezjologiczna Congara po Soborze nie zawiera jakiejś syntezy, nie ma zakończenia. Francuski dominikanin wie, że chodzi tutaj o długi i powolny proces. Rozpoczął się on już przed Soborem, a fundamentalna wizja teologiczna Kościoła zawarta w Konstytucji dogmatycznej Lumen gentium stała się jego ważnym etapem ${ }^{32}$. Proces ten po Soborze nie został jednak zakończony.

${ }^{30}$ Zob. tenże, Aktualność pneumatologii [w:] tenże, Wezwani do życia, tłum. A. Ziernicki, Kraków 1999, s. 79-96.

31 Zob. tamże, s. 89-95. Sformułowania czterech pierwszych tez za: M. Jagielski, L'Église..., s. 394-395.

32 Y. Congar, Aktualność pneumatologii..., s. 84-89. 


\section{U początku procesu zmiany pneumatologicznego rozumienia Kościoła: odejście od modelu „Societas perfecta” do modelu „De Populo Dei”}

Tak jak to czyni sam Congar, aby zrozumieć realną pneumatologię zastosowaną w Konstytucji dogmatycznej o Kościele Lumen gentium, należy wyjaśnić najpierw sposób przedstawiania roli Ducha Świętego w Kościele katolickim przed Soborem Watykańskim II.

W okresie przedsoborowym kwestia pneumatologii w eklezjologii była kwestią zupełnie drugorzędną. W doszukiwaniu się działania Ducha Świętego w Kościele podkreślano wymiar indywidualny człowieka, powiązany z jego duszą. Mówienie o wpływie Ducha Bożego w Kościele polegało na przywoływaniu postaci wybitnych świętych, inicjatorów różnych dzieł czy założycieli zakonów. Rolę Ducha Świętego w Kościele przed Soborem rozumiano jako Tego, który zapewniał wszystko, co było Kościołowi potrzebne. Mówienie o Duchu Świętym za każdym razem brzmiało jak pewnego rodzaju usprawiedliwienie instytucji Kościoła ${ }^{33}$. W jurydycznej wizji Kościoła sprowadzano rolę Ducha Świętego do kwestii wystarczalności sakramentów. Jego działanie łączono z problematyką ważności Eucharystii czy nieomylności nauczania w Kościele ${ }^{34}$.

Dla Congara oznaką realnego wprowadzenia pneumatologii do eklezjologii już przed Soborem Watykańskim II było odejście od wizji Kościoła jako „społeczności całkowicie gotowej, [od wizji] wielkiego, świętego, dobrze zmontowanego mechanizmu - [i przejście] do wizji Kościoła jako aktywnie i aktualnie stwarzanego przez Boga"35. Congar zauważa, że już przed Soborem dokonuje się odejście od rozumienia Kościoła jako establishmentu. W zmianie fundamentalnej wizji teologicznej Kościoła pojawia się wizja Kościoła jako ludu Bożego.

Pierwszy zauważył potrzebę owego teologicznego przejścia wybitny niemiecki teolog Johann Adam Möhler (1796-1838). Podobne rozeznanie odnowionego spojrzenia na Kościół wyznaczył konwertyta John Henry Newman (1801-1890). Yves Congar należał do teologów wpisujących swoje badania w ową odnowę. Jego teologia współtworzyła théologie nouvelle, tzw. nowa teologię. Do środowiska jej twórców, oprócz Congara, należeli z samej tylko Francji, m.in.: Henri de Lubac, Marie-Dominique Chenu, Pierre Teilhard de Chardin, Jean Daniélou, Jean Mouroux.

W procesie odnowy eklezjologii nie można pominąc istotnego wpływu encykliki papieża Piusa XII Mystici Corporis z 1943 roku. Congar zaznacza, że encyklika ta uwypukla niepodważalny fakt istnienia charyzmatycznego wymiaru Kościoła:

\footnotetext{
33 Por. tamże, s. 83.

34 Por. M. Jagielski, L'Église dans le temps..., s. 373.

35 Y. Congar, Aktualność pneumatologii..., s. 86.
} 
Mystici Corporis [...] wprowadziła na powrót charyzmaty do eklezjologii, a także mówiła o Duchu Świętym jako o wewnętrznej zasadzie życia Ciała [M]istycznego. Uczyniła to we właściwym sobie kontekście: myślę o utożsamieniu [M]istycznego Ciała Chrystusa z ciałem społecznym i hierarchicznym ${ }^{36}$.

Congar docenia mówienie o wymiarze charyzmatycznym Kościoła przez wspomnianą encyklikę, ale zaznacza powagę i sens świadomego definiowania Kościoła jako społeczności ${ }^{37}$. Jak to za chwilę wyjaśnię, w tym ostatnim wymiarze zawiera się bowiem ekonomia objawienia. Przestrzeń historii jest jak najbardziej przestrzenią działania Ducha Świętego.

\section{Eklezjologia pneumatologiczna w Konstytucji dogmatycznej Lumen gentium ważnym etapem ciąglego procesu}

Sobór Watykański II nie definiuje Kościoła już więcej jako „przede wszystkim” societas inaequalis, hierarchica, ale jako „najpierw” Populus Dei. Sobór wyraźnie określił swoje nowe rozumienie fundamentu Kościoła, że jest nim lud Boży, lud mesjanistyczny ${ }^{38}$. Jak zauważa Congar, przekraczamy wizję, w której „Bóg, który stworzył hierarchię, w ten sposób aż nadto zatroszczył się o wszystko, czego potrzeba, aż do końca czasów" (stwierdzenie wybitnego niemieckiego teologa Johanna Adama Möhlera) $)^{39}$. Congar wyjaśnia pneumatologiczny wkład soborowej Konstytucji o Kościele w następujących słowach:

36 Tamże s. 86-87.

37 Potrzeba ujęcia wizji Kościoła zarazem charyzmatycznego, jak i społeczno-hierarchicznego, została przedstawiona w numerze 51. encykliki Mystici Corporis Piusa XII w następujących słowach: „[w]łaściwe znaczenie nazwy Ciała mistycznego ostrzega nas, iż Kościół, doskonała w swoim rodzaju społeczność, nie składa się wyłącznie z czynników społecznych i nie opiera się jedynie na czynnikach i stosunkach prawnych. [...] Wprawdzie podstawy prawne, które wchodzą także w skład budowy Kościoła i z boskiego ustanowienia Chrystusa są jego podłożem, przyczyniają się do osiągnięcia ostatecznego celu. Jednakże to, co dźwiga społeczność chrześcijańską na wyżyny, zupełnie przekraczające wszelki porządek przyrodzony, jest dziełem Ducha Świętego. On to, jako źródło łask, darów i wszelkich charyzmatów, bezustannie Kościół przenika, napełnia go i w nim działa [...])" (Pius XII, Encyklika o Mistycznym Ciele Jezusa Chrystusa. Mystici Corporis Christi, tłum. A. Żychliński, Kielce 1945, s. 35-36.

${ }_{38}$ Autorem pojęcia „ludu mesjanistycznego”, znajdującego się w tekście Lumen gentium 7, jest Yves Congar. Teolog ubolewa, że wyrażenie to jest prawie całkowicie pomijane w różnych posoborowych komentarzach, gdy tymczasem wpisuje się doskonale w odnowioną perspektywę wizji Kościoła. Por.: tenże, Lumen Gentium..., s. 158; tenże, D’une «ecclésiologie en gestation» à Lumen Gentium (Chap. I et II) [w:] tenże, Le Concile de Vatican II. Son Église. Peuple de Dieu et Corps du Christ, (TH, n 71), Paris 1984, s. 123-136, tu: s. 135.

39 To samo stwierdzenie J.A. Möhlera w oryginale: „Gott schuf die Hierarchie und für die Kirche ist nun bis zum Weltende mehr als genug gesorgt”(zob. Y. Congar, Lumen Gentium ..., s. 148. 
Sobór dokonał podwójnego przekroczenia: w wymiarze pionowym — poprzez skoncentrowanie się na aktualnym działaniu Boga — i w wymiarze poziomym — uznając dary Boga we wszystkich wiernych. Lecz ten wymiar „poziomy” jest tylko hojnością i wolnością wymiaru „,pionowego". A zatem pneumatologia! $!^{40}$.

„Wymiar pionowy” eklezjologii pneumatologicznej na Soborze, który określam dalej jako „wymiar wertykalny”, Congar interpretuje jako budowanie Kościoła osobiście przez Boga:

To Bóg buduje swój Kościół. To Bóg nas powołuje (Rz 1,6; lud Boży, Kościół Boży, 1 Kor 1,1; 2 Kor 1,1). To Bóg udziela darów posługiwania (1 Kor 12,4-11). To Bóg daje wzrost (1 Kor 3,6). To od Chrystusa całe Ciało otrzymuje harmonię i spoistość (Ef 4,16). To Bóg ustanowił jednych apostołami, a innych nauczycielami i prorokami, każdemu dając miejsce w Ciele (1 Kor 12, 28n) Jeśli chodzi o Chrystusa, święty Paweł mówi o Nim nie tyle jako o fundatorze (który założył w przeszłości doskonałą społeczność, societas perfecta), ile o ciągle aktualnym fundamencie (por. 1 Kor 3,11n). Nie przeczy to odziedziczonej instytucji, lecz nie pozwala na to, by sprowadzać do niej wszystko ${ }^{41}$.

W ,wymiar poziomy” (patrz dalej ,wymiar horyzontalny”) pneumatologii Kościoła Congar wpisuje uniwersalne znaczenie włączenia wszystkich wiernych w służbę Kościoła na płaszczyźnie darów naturalnych i darów łaski, zwanych charyzmatami:

\begin{abstract}
Aby zbudować swe żywe Ciało, Chrystus rzeczywiście nie tylko przyjął na trwałe i w drodze ustanowienia pewne środki widzialne i społeczne, co lubię nazywać strukturami przymierza: sakramenty, apostolstwo i wywodzące się z niego posługi. Wzywa On także wszystkich wiernych, by wnieśli własny wkład poprzez włączenie w służbę jego dziełu tych darów naturalnych i darów łaski, które nazywa się charyzmatami ${ }^{42}$.
\end{abstract}

Niewątpliwie powyższe dwa wymiary — wertykalny i horyzontalny — są przyczynkiem Soboru Watykańskiego II do eklezjologii pneumatologicznej i należy je potraktować jako fundamentalny klucz Congara do interpretacji soborowej pneumatologii. W tych dwóch wymiarach zawierają się pozostałe, wspomniane w pięciu tezach, refleksje tego teologa. Ponieważ są one syntezą wszystkich jego wcześniejszych badań, więc analiza tutaj podjęta będzie równocześnie wskazaniem innych źródeł dotyczących pneumatologii tego teologa. Proponuję w ostatniej części tego studium przedstawić pneumatologiczne akcenty eklezjologii w Lumen gentium w tym właśnie kluczu. Analiza przeze mnie proponowana jest w pewien sposób próbą uważnej lektury artykułu Congara Aktualność pneumatologii. Wszystkie jego tezy i postulaty eklezjologii pneumatologicznej

\footnotetext{
40 Tenże, Aktualność pneumatologii..., s. 86-87.

41 Tamże.

42 Tamże.
} 
tam przedstawione będę próbować wyraźniej przypisać do wspomnianych przez niego dwóch wymiarów przyczynku Soboru w analizowanej tutaj kwestii pneumatologii. Studium to uzupełni brak podjęcia przez samego Congara szczegółów owego przypisania. Do wymiaru „wertykalnego” proponuję odnieść pierwszą, czwartą i piątą tezę eklezjologii pneumatologicznej Congara, do wymiaru „horyzontalnego" zaś tezę drugą i trzecią.

\section{Eklezjologia pneumatologiczna w Lumen gentium — wymiar wertykalny}

Przed Soborem Watykańskim II opisywanie w teologii działania Pana Boga odnosiło się do procesu już wykonanego przez Chrystusa w Kościele. Chodzi o metodę scholastyczną, która interpretowała działania Boga w sposób czysto spekulatywny, konceptualny i dedukcyjny ${ }^{43}$.

W zamyśle Congara chodzi o postrzeganie działania Ducha Świętego w wymiarze aktualności. Pojęcie 'aktualności’ zakłada czas, a zatem historyczność i niezwykle ważne w odnowionej teologii pojęcie 'ekonomii'. W takim podejściu rozwój procesu pneumatologicznego ujęcia Kościoła odnieść należy do tajemnicy wcielenia Syna Bożego. Dotykamy tutaj niezwykle istotnego dla teologii Congara aspektu historycznego, a zarazem eschatologicznego teologii Kościoła i działania w nim Pana Boga. Tak jak autor ten bardzo tego pragnął, z racji fundamentu swoich badań teologicznych (por. cele szkoły Saulchoir), Sobór wpisał wyjaśnienie realizacji wielkiego planu Zbawienia w historię. Rzeczywiście te dwa aspekty są wszechobecne w tekście Lumen gentium. Słowo 'historia' w tekstach Soboru pojawia się blisko $300 \mathrm{razy}^{44}$. Natomiast temat eschatologii został opracowany nawet jako osobny, ósmy rozdział tej konstytucji ${ }^{45}$.

W analizowanym tutaj artykule Aktualność pneumatologii Congar wyjaśnia temat działania Boga w Kościele najpierw w tezie pierwszej:

${ }^{43}$ Zob. interesującą analizę krytyczną metody scholastycznej w teologii, zaproponowaną przez Marie-Dominique Chenu. Francuski dominikanin wykazuje potrzebę zastosowania teologii praktycznej: „Theoria bez Praxis jest bezkrwawa. Traci ona nie tylko swój zapał, lecz również swoją prawdę ewangeliczną": M.D. Chenu, Theoría et praxis en théología, „Ciencia Tomista” 99 (1972), s. 3-10, tu: s. 4.

44 Jak podkreśla w swoim słynnym wywiadzie Y. Congar, uczeń M.D. Chenu oraz kontynuator tego samego kierunku badań: ,[w]szystko jest absolutnie historyczne, również osoba Jezusa Chrystusa. Tomasz z Akwinu jest historyczny. Paweł VI jest historyczny. I mój punkt widzenia również wpisuje się w pewną historię..." (Y. Congar, Jean Puyo..., s. 43).

${ }^{45}$ Por. film Vatican II, des images, des témoins. Le Cardinal Etchegaray, Mgr Gilson et le Père Cancouët racontent le Concile Vatican II zrealizowany przez Véronick Beaulieu-Mathivet, Paris 2006. 
Kościół nie jest całkowicie gotowy, lecz nieprzerwanie się buduje, albo raczej jest budowany przez Boga. Całość nie jest dana i jak gdyby sprefabrykowana w szczegółowo określonych ramach. Jest tu miejsce dla osobistego wkładu poszczególnych osób i w tym sensie — dla ich kreatywności ${ }^{46}$.

Ta pierwsza teza Congara sformułowana została już przed Soborem. Dominikanin mówił o aktualizacji życia po raz pierwszy w swojej słynnej książce Chrétiens désunis. Principes d'un «œecuménisme» catholique, opublikowanej w $1937 \mathrm{roku}^{47}$ :

Duch Święty, który ożywia całe ciało, aktualizuje w jego pamięci rzeczy, które są w nim zdeponowane przez naszego Pana jako żywe nasiona od samego początku, lecz które nie przybyły jeszcze i nie zostały rozpoznane w aktualności życia. To w tej perspektywie należy dostrzec rolę w Kościele, owej niesłychanej płodnej różnorodności doświadczeń religijnych: [...] wszystko to, bez wnoszenia czegokolwiek z zewnątrz do skarbu katolickości, który jest substancjalnie dany od momentu Pięćdziesiątnicy, aktualizuje w owym darze swoje bogactwo, w nim żyjąc od wewnątrz i wyjaśniając go na tysiąc nowych sposobów, które to realizują i wyrażają „niezbadane bogactwa Chrystusa” (Ef 3,8) ${ }^{48}$.

W pneumatologicznej wizji Congara Kościół nie jest całkowicie zakończony. Znajduje się on pomiędzy Alfą a Omegą samego Chrystusa. Jest założony przez Chrystusa, ale jest również zadany do dalszej realizacji ${ }^{49}$. Rolę Trzeciej Osoby Trójcy Świętej w Kościele należy rozumieć w tym kontekście jako aktualizującą to, co zostało wcześniej założone przez Chrystusa. Znamienne jest tutaj życzenie Congara wyrażone już na rok przed otwarciem obrad soborowych: „[n]ie jest tylko naszą ideą, aby przedstawiać Kościół, wzywając do powrotu do źródeł, chodzi o naszą ideę Boga jako Boga Żyjącego, i stając wobec Niego, o naszą ideę Wiary" 50 .

Pionowy wymiar osobistego działania Boga w Kościele odpowiada również czwartej tezie Congara. Teolog postuluje w niej, że potrzebne jest nadanie całej eklezjologii wymiaru trynitarnego. Congar wyjaśnia: „,[p]rzyjąć, że Trójca Świę-

${ }^{46}$ Y. Congar, Aktualność pneumatologii..., s. 89.

${ }^{47}$ W cytowanej tutaj książce Congara, jak podkreśla M. Jagielski: „znajdujemy korzenie wielkiej proklamacji 'Wierzę w Ducha Świętego', do której tak często powraca [francuski teolog] w swoim duchowym rozwoju oraz w swojej teologicznej refleksji”' (tenże, L'Église..., s. 366).

${ }^{48}$ Y. Congar, Chrétiens désunis. Principes d’un «æecuménisme» catholique, (US, $\left.\mathrm{n}^{\circ} 1\right)$, Paris 1937, s. 317-318. Por. M. Jagielski, L'Église ..., s. 366.

${ }^{49}$ M. Jagielski, L'Église..., s. 370.

50 „Ce n'est pas seulement notre idée et notre présentation de l'Église qu'il faut renouveler aux sources, c'est notre idée de Dieu comme Dieu Vivant et, lui faisant face, notre idée de la Foi". Y. Congar, Veux pour le concile. Enquête parmi les chrétiens, I: Catholique. Yves M.J. Congar, o.p., „Esprit” 301 (1961), s. 691-700, tu: s. 695. Cyt. za: M. Jagielski, L'Église ..., s. 365. 
ta stanowi prawzór Kościoła, to uznać i uzasadnić, że jego istotą jest wspólnota osób, to uznać i uzasadnić różnorodność sytuacji oraz konieczność komunikacji i wymiany między nimi” ${ }^{51}$. Francuski dominikanin podkreśla:

\begin{abstract}
'hierarchia' nie ma monopolu na Ducha Świętego, nie jest ona jakimś zbiornikiem, który by udzielał z wysoka Jego bogactw. [...] Duch Święty zamieszkuje również w wiernych, a wyświęceni pasterze sami powinni być przede wszystkim wiernymi. Jakież zdrowie teologiczne i zarazem duszpasterskie bije z tych słów świętego Augustyna, które tak często powtarzał: Vobis sum episcopus, vobis christianus, jestem dla was biskupem, lecz wraz z wami jestem chrześcijaninem, wraz z wami jestem sługą, wraz z wami uczniem, wraz z wami grzesznikiem, a także wraz z wami owcą pod laską jednego Pasterza... Oznacza to przemienność i relacje wymiany między funkcją przedstawiciela instytucji ustanowionej przez Chrystusa i życiem osobistym dzięki łasce Ducha Świętego ${ }^{52}$.
\end{abstract}

Teza Congara tutaj wyjaśniona w relacji do tekstu Lumen gentium ma charakter bardziej postulatu aniżeli stwierdzenia. Dotykamy tutaj szerszego problemu krytyki redakcji konstytucji soborowej, w której zauważa się brak sformułowania szczegółowej korelacji pomiędzy rozdziałem II i III tego dokumentu, czyli relacji pomiędzy biskupami a pozostałymi wiernymi ${ }^{53}$. $\mathrm{Z}$ drugiej jednak strony w tekście konstytucji jest rzeczywiście zastosowany wymiar trynitarny refleksji nad Kościołem. Ojcowie zdefiniowali Kościół w logicznie przedstawiającym się ciągu teologicznego wyjaśnienia, w którym, w przeciwieństwie do Soboru Watykańskiego I, refleksja wychodzi od Trójcy Świętej. Co więcej, od początku treści Lumen gentium (notabene tak samo jest w Ad gentes i Dei verbum) trynitarność otrzymała tutaj perspektywę ekonomii. „Kościół jest realizacją ziemską i historyczną poprzez komunikację łaski i zbawienia pochodzącego od Boga" 54 . Trynitarność, a co za tym idzie pneumatologia, korelowały z przedstawieniem Kościoła również jako Ciała Chrystusa i Świątyni Ducha. Tak jak to podkreślała myśl Congara: Ciało Chrystusa uzupełnia sens nowego ludu Bożego, czyli nową ekonomię. Chodzi o „ekonomię obietnic spełnionych w postaci Wcielenia Syna i daru Ducha Świętego, Obiecane — czyli lud Boży — uzyskuje sta-

\footnotetext{
${ }^{51}$ Y. Congar, Aktualność pneumatologii..., s. 92.

52 Tamże, s. 92-93.
}

53 J. Grootaers, wybitny specjalista belgijski w kwestii laikatu na Soborze Watykańskim II, precyzuje: „napięcia soborowe wokół rozdziału III De Ecclesia (dotyczące kolegium biskupów) zmobilizowały uwagę większości Ojców soborowych do tego stopnia, że opracowanie rozdziału dotyczącego ludu Bożego i więzi pomiędzy II i III rozdziałem było niewystarczające”, por. tenże, Peuple de Dieu [w:] Catholicisme. Hier. Aujourdhui. Demain, encyclopédie publiée sous le patronage de l'Institut catholique de Lille par G. Mathon, G.H. Baudry, P. Gilluy, E. Thiery, t. 49: V «Perpignan-Pie V», Paris 1986, s. 97-121, tu: s. 119.

54 „L'Église est une réalisation terrestre et historique par communication de grâce du mystère trinitaire”. Zob. M. Jagielski, L’Église..., s. 388. 
tus, który można wyrazić, jedynie odwołując się do kategorii i do teologii Ciała Chrystusa"55. Jak syntetyzuje pierwszą część Konstytucji Lumen gentium Jean Rigal: „Przedwieczny Ojciec wezwał nas do życia wiecznego. Do Syna należy zrealizowanie zamysłu zbawienia Ojca. Owa misja będzie kontynuowana i aktualizowana, lecz we właściwy sposób przez Ducha w czasie historii (KK 2-4)" Tajemnica Kościoła w Vaticanum Secundum „nie jest ograniczona zatem do jednej z Osób Boskich, lecz wypływa ona z Trójcy Świętej jako jej źródła — jest to zaangażowanie Boga Trójjedynego w celowości świata: Kościół jest postrzegany jako «kres w [rzeczywistości] ludzi i w rozwoju świata dla ludzi i dla świata, [kres] życia wewnątrz-boskiego, Pochodzeń trynitarnych»»"57. Warto zauważyć tutaj pierwszy moment znalezienia takiego rozwiązania teologicznego. Pojawił się on podczas tworzenia nowego schematu De Ecclesia, na bazie tekstu nazwanego od jego autora schematem Philipsa. Oto co pisze autor, G. Philips, w swoim dzienniku soborowym pod datą 1 marca 1963 roku, to znaczy w momencie zamknięcia redakcji I rozdziału Lumen gentium:

Wymyśliłem następujący plan: najpierw l’Ecclesia de Trinitate, to znaczy [Kościół] wobec Ojca, Syna i Ducha Świętego. Następnie relacje osobowe Kościoła i Chrystusa z ideą Corpus Mystici i inne biblijne figury Kościoła. W końcu Kościół na ziemi i jego relacja do katolików $\mathrm{i}$ innych chrześcijan i wobec wszystkich ludzi ${ }^{58}$.

\section{Eklezjologia pneumatologiczna w Lumen gentium - wymiar horyzontalny}

We wspomnianym artykule Aktualność pneumatologii Yves Congar zaznacza jako tezę drugą, że Kościół cieszy się pełnią Ducha tylko w całości darów przekazanych wszystkim członkom ${ }^{59}$. Sformułowanie odnosi się wyraźnie do poziomu horyzontalnego, czyli wspólnotowego Kościoła. Chodzi o obdarowanie darami

55 Y. Congar, Kościót, jaki kocham, tłum. A. Ziernicki, Kraków 1997, s. 36.

56 „Le Père éternel nous a appelés à la vie divine. Il appartient au Fils de réaliser le dessein de salut du Père. Cette mission sera poursuivie et actualisée, mais de manière propre, par l'Esprit dans le temps de l'histoire (LG, n 2-4)”. J. Rigal, Le Christ et l'Esprit fondement de l'Église, „Prêtres Diocésains" 1366 (1999), s. 181-197, tu: s. 186.

57 „,[Le mystère de l'Eglise] n'est plus limité à l'une des Personnes divines, mais elle vient de la Trinité comme de sa source - c'est l'engagement de Dieu trinitaire dans le destin du monde: L'Église est vue 'comme le terme, dans les hommes et dans le devenir du monde, pour les hommes et pour le monde, de la vie intra-divine, des Processions trinitaires"'. M. Jagielski, L'Église..., s. 388. Cytat za: Y. Congar, Les implications..., $\left(\mathrm{TH}, \mathrm{n}^{\circ} 61\right)$, s. 129.

58 „J'ai conçu le plan suivant: d'abord l'Ecclesia de Trinitate, c.-à-d. face au Père, au Fils et au Saint-Esprit. Ensuite les relations personnelles de l'Église et du Christ, avec l'idée du Corpus Mystici et les autres représentations scripturaires. Enfin l'Église sur terre et sa relation aux catholiques, aux autres chrétiens et à tous les hommes”. G. Philips, K. Schelkens, Carnets conciliaires..., s. 97.

${ }_{59}$ Zob. Y. Congar, Aktualność pneumatologii..., s. 89. 
Ducha Świętego wszystkich członków Kościoła. Zdefiniowanie charyzmatycznego wymiaru Kościoła przez Sobór Watykański II znalazło się w 12. numerze I rozdziału Lumen gentium. Fragment ten wyjaśnia pentekostalny wymiar Kościoła, w którym istotną rolę odgrywają wszyscy wierni świeccy ${ }^{60}$. W przekazie literalnym tego fragmentu konstytucji chodziło o ukazanie uświęcenia Kościoła, które rozszerza się na lud Boży przez sakramenty, ministeria (= posługi), cnoty $\mathrm{i}$ dary specjalne zwane charyzmatami ${ }^{61}$. Dla Yves'a Congara pneumatologia zapisana $\mathrm{w}$ tym fragmencie posiadała znaczenie słusznego dowartościowania w eklezjologii Kościołów lokalnych:

Kościół znajduje pełnię Ducha tylko w całości darów udzielonych wszystkim członkom. Nie jest czymś w rodzaju piramidy, której podstawa, całkowicie bierna, przyjmuje wszystko od wierzchołka. A taki właśnie model panował w umysłach przez całe wieki. Kościół jest wspólnotą. Oczywiście ma on swą strukturę i to właśnie nadaje realną treść wyrażeniu „wspólnota hierarchiczna". Chodzi również o konkretną strukturę, która ma swoje wymogi i środki wyrazu. [...] Należy to dostrzec nie tylko w perspektywie rozpoznania darów, jakie wnoszą poszczególne osoby w ramach partykularnych wspólnot: dotyczy to również bardzo żywej dziś odnowy poczucia oryginalności Kościołów lokalnych w łonie powszechnej, czyli katolickiej, komunii ${ }^{62}$.

Refleksja Congara wyraźnie wskazuje na totalność Kościoła w jego lokalności. Sobór Watykański II świadomie dowartościował znaczenie partykularności Kościoła, wykazując, że każdy z Kościołów lokalnych posiada wymiar katolickości ${ }^{63}$. Partykularne wspólnoty, które należy rozumieć generalnie jako diecezje (niekiedy jako prałatury personalne ${ }^{64}$, prałatury terytorialne) nie są tylko częścia, lecz porcja ludu Bożego ${ }^{65}$. Posiadają wszystkie jakości i właściwości całego Ko-

${ }^{60}$ Por. L.J. Suenens, Souvenirs et Espérances, Paris 1991, s. 25.

${ }^{61}$ Numer 12 Lumen gentium powstał na podstawie słynnej interwencji kardynała Suenensa, wygłoszonej podczas Soboru Watykańskiego II 22 października 1963 roku. Przemówienie zostało przygotowane przez teologa Hansa Künga na prośbę prymasa Belgii i wyrażało wolę większości biskupów poparcia wpisania do definicji Kościoła w Konstytucji Lumen gentium charyzmatycznego rozumienia jego natury. Por.: AS II/III, s. 169. FConc. Suenens nr 1534 (tekst przemówienia kard. Suenensa. „La Revue Nouvelle” nr 38 décembre 1963, s. 481-483). Zob. również: FConc. Suenens nr 1531 (projekt tekstu H. Künga); FConc. Suenens nr 1533 (projekt tekstu G. Thilsa); FConc. Suenens nr 1532 (ostateczny projekt przemowy in aula z poprawkami kard. Suenensa, A. Prignona, P. Schoenmaeckersa). FConc. Suenens nr 1534 (przemowa kard. Suenensa in aula). H. Küng, The charismatic structure of the Church, „The Catholic World” august (1965), s. 302-321, tu: s. 302-306, tekst art.: FConc. Suenens nr 1540.

${ }^{62}$ Y. Congar, Aktualność pneumatologii..., s. 89-90.

${ }_{63}$ Jak podkreślają Ojcowie Soboru, Kościół jest rzeczywistością w przestrzeni terytorialnej (por. DB 23 i KPK 372 § 1), wpisującą się w różne kultury ludzkości (por. DA 22, 2).

${ }^{64}$ Por.: DP 10, KPK 294-297.

${ }^{65}$ Tak jak powiedział wybitny historyk włoski prof. Giuseppe Alberigo: „Kościół lokalny jest "pars pro toto et non pars in toto»" (tenże, Institutions exprimant la communion entre l'episcopat universel et l'évêque de Rome [w:] Les Églises après Vatican II. Dynamisme et 
ścioła (KK 17, 26, 28. Por.: DA 3,4; DB 11; DM 8; DP 7) ${ }^{66}$. W takim rozumieniu, tak jak podkreśla to Konstytucja dogmatyczna o Kościele w numerze 13., pełnia darów jest obecna w każdym z tych Kościołów:

Dzięki tej katolickości poszczególne części przynoszą innym częściom i całemu Kościołowi właściwe sobie dary, tak iż całość i poszczególne części wzrastają na skutek owej wzajemnej łączności wszystkich oraz dążenia do pełni w jedności ${ }^{67}$.

Poziom horyzontalny eklezjologii pneumatologicznej zastosowanej w Konstytucji dogmatycznej o Kościele koreluje również z trzecią tezą Congara wyrażoną w artykule Aktualność pneumatologii. Sformułowana jako myśl, że subtelność działania Ducha Świętego aktualizuje dzieło Chrystusa, respektując każdą osobę, odnosi się do wymiaru wnętrza, niepowtarzalności i oryginalności każdego z członków Kościoła. Congar wyjaśnia:

Jedną z właściwości ducha (Ducha) jest subtelność. Właśnie dzięki niej, będąc jednym i tym samym, może On wypełniać cały świat i przenikać wnętrze każdej osoby, doskonale respektując jej osobową wewnętrzność i niepowtarzalność (por. 1 Kor 2,10-11; por. Gal 4,6, Duch wysłany do serc). [...] Trzeba przyznać Duchowi Świętemu działania w pewnym sensie własne: „poprzez apropriację”, mówi teologia, nie dając jeszcze żywego odczucia wspaniałej rzeczywistości, jaka się kryje za tym pojęciem, ani też nie przekonując w sposób oczywisty o tym, że ta konceptualizacja ma swe źródło w Piśmie [Ś]więtym. Mówi się więc, jak tylko może [tzn. teologia], o wolności Ducha. Jednakże — a zastrzeżenie to wcale nie oznacza, że czynimy Go zwykłym „wikarym Chrystusa”, zwykłym wykonawcą poleceń Chrystusa - nie można Mu przypisywać autonomii treści urzeczywistnianego dzieła. Nie można oderwać Ducha Świętego od Chrystusa. Duch Święty aktualizuje w wydarzeniach dzieło Chrystusa ${ }^{68}$.

Refleksja Congara opisująca w powyższych słowach działanie Ducha Świętego w Kościele oparta została na interpretacji św. Tomasza z Akwinu. Odwołanie się do koncepcji działania Ducha Świętego w Kościele „przez apropriację” wpisuje myśl Congara do wielkiej kontynuacji Tradycji Kościoła. Akwinata pierwszy wprowadza pneumatologię do eklezjologii. Jego teoria apropriacji przyczy-

prospective. Actes du Colloque international de Bologne - 1980, éd. G. Alberigo, Paris 1981, s. 259-289, tu: s. 261.

${ }^{66}$ Temat ten był analizowany szczegółowo zaraz po Soborze przez H. de Lubaca, Y. Congara, następnie przez H. Legranda. Por.: H. de Lubac, Les Églises particlières dans l'Église universelle, (Intelligence de la foi), Paris 1971, s. 30; Y. Congar, De la communion des Églises à une ecclésiologie de l'Église universelle [w:] L'Épiscopat et l'Église universelle, dir. de tenże, B.D. Dupuy, (UnSa), Paris 1964, s. 227-260; H. Legrand, Enjeux théologiques de la revalorisation des Églises locales et de l'Église entière, „Concilium” 71 (1972), s. 49-58; tenże, La réalisation de l'Église en un lieu [w:] Initiation à la pratique de la théologie, dir. de B. Lauret, F. Refoulé, t. III: Dogmatique 2, Paris 1993, s. 143-344; tenże, Les évêques, les Églises locales et l'Église entière [w:] Le ministère des évêques au concile Vatican II et depuis, Paris 2001, s. 201-260.

${ }^{67}$ Sobór Watykański II..., s. 116.

${ }^{68}$ Y. Congar, Aktualność pneumatologii..., s. 90-91. 
nia się jednak do niejasnej interpretacji roli Ducha Świętego w kontekście całej Trójcy Świętej ${ }^{69}$. Nie przypadkiem Congar, wspominając tę metodę, podkreśla zaraz, że działanie Ducha Świętego nie polega na pomocniczości misji Chrystusa (Duch Święty niejako „wikarym Chrystusa”). Duch Święty jest wolny w swoim działaniu, chociaż nie należy Jego działania odrywać od misji Chrystusa ${ }^{70}$. „Duch Święty [...] nie czyni innego dzieła niż to, które jest z Chrystusa" "71.

\section{Konkluzja}

Niniejsza analiza zaprezentowała spojrzenie na tekst Konstytucji dogmatycznej o Kościele Soboru Watykańskiego II z perspektywy problematyki eklezjologii pneumatologicznej zaproponowanej przez Yves'a Congara. Spojrzenie takie pozwala wysnuć cztery podstawowe wnioski.

Po pierwsze stwierdzam, że pneumatologiczne akcenty w eklezjologii zawartej w Lumen gentium wiążą się silnie z odnowionym podejściem do kwestii samej wizji Kościoła. Wpisuje się ona w odnowione zrozumienie Kościoła, którego zręby zostały sformułowane już przed Soborem Watykańskim II. To właśnie w tym okresie dochodzi do zmiany akcentów w przedstawianiu Kościoła: uwypuklano już mniej hierarchiczny wymiar Kościoła, a bardziej duchowy i wspólnotowy. Fundamentalna zmiana w ujęciu Kościoła polegała na odejściu od koncepcji societas perfecta na rzecz koncepcji ludu Bożego i rozumienia Kościoła jako Mistycznego Ciała Chrystusa. Sobór przyjął to nowe podejście, jednocześnie nie bagatelizując wymiaru instytucjonalnego Kościoła, rozumianego jako jego

${ }^{69}$ Święty Tomasz określa działanie Ducha Świętego jako akt, przez który Kościół żyje cnotami teologalnymi. Przez cnoty teologalne Kościół obdarzony jest cnotami moralnymi, które jako swój przedmiot mają Boga i przez które Duch Święty nadaje poruszenie. Duch, który jest tutaj darem łaski, będąc Bogiem, dokonuje dzieła asymilacji. Jednakże, zdaniem Akwinaty, Duch Święty nie posiada żadnej przyczynowości własnej ani szczególnej. Jest podmiotem apropriacji, gdy tymczasem Chrystus w swojej ludzkiej naturze połączonej in persona z Trójcą Świętą jest przyczyną prawdziwą, a nawet instrumentalną. Niniejszą krytykę wskazał prof. Vincent Holzer zasiadający w jury, w charakterze promotora, podczas obrony doktoratu François-Marie Humanna, 17 grudnia 2007 roku na ICP w Paryżu. Doktorat zatytułowany Le christologie pneumatologique et ses enjeux. La relations entre le Christ et l'Esprit dans l'oeuvre d'Yves-Marie Congar podejmuje studium problematyki chrystologicznej w pneumatologii Congara.

${ }^{70}$ Tak jak podkreślił to prof. Vincent Holzer podczas obrony doktoratu F.M. Humanna (zob. przypis powyżej), zauważa się potrzebę analizy krytycznej pneumatologii Congara. W kwestii interpretacji Trójcy Świętej już w latach trzydziestych XX wieku słusznie przestrzegał przed pomieszaniem m.in. Pierre Duvigneau. W swoim artykule z 1937 roku podkreśla on potrzebę dogłębnego zrozumienia kompleksyjności interpretacji teologicznych w tej kwestii. Zob. tenże, „Supplement Vie Spirituelle", février 1937.

${ }_{71}$, „'Esprit $[\ldots]$ ne fait pas une autre œuvre que celle du Christ”. Y. Congar, Les implications..., $\left(\mathrm{TH}, \mathrm{n}^{\circ} 71\right)$, s. 176. 
struktura i wymiar społeczny. W opinii Congara decyzja taka koreluje z pneumatologicznym ujęciem Kościoła. Kościół jako społeczeństwo wskazuje na wymiar Ciała Chrystusa animowanego przez Ducha Świętego. Jeśli temat ,animacji” Kościoła przez Ducha Świętego Congar przypisuje roli Chrystusa uwielbionego, to Sobór rozumie takie samo znaczenie działania Ducha Świętego, mówiąc o sakramentalności w Kościele.

W drugim wniosku wyprowadzonym z teologicznej refleksji Congara stwierdzam, że w tekście Lumen gentium należy doszukiwać się eklezjologii pneumatologicznej przede wszystkim w wymiarze chrystologicznym. Tak jak to wyjaśnia Yves Congar w dialogu z zarzutami niektórych obserwatorów Soboru Watykańskiego II, opisanie w taki sposób Kościoła nie deprecjonuje ani nie pozbawia możliwości pneumatologicznego zrozumienia Kościoła. Wynika to z jednej strony z tradycji łacińskiej, starającej się zawsze podkreślać rolę Chrystusa w działaniu Kościoła, z drugiej strony również z właściwego rozumienia dwóch misji: Syna i Ducha w Kościele. W ulubionym obrazie Congara, zaczerpniętym od św. Ireneusza z Lyonu, Bóg jawi się jako operujący w Kościele (świecie) swoimi dwoma dłońmi. Dwie ręce Boga są misjami Chrystusa i Ducha Świętego. Druga misja wpisuje się w pierwszą. Przez obie misje Bóg osobiście formuje swój Kościół. Misja Chrystusa charakteryzuje się tworzeniem struktury, gdzie Słowo Wcielone wchodzi w rzeczywistość tego świata, a Kościół, będąc niejako sakramentem, jest kontynuacją tej samej Tajemnicy. Natomiast misję Ducha Świętego charakteryzuje funkcja ożywiania struktury stworzonej przez Chrystusa. To, co Congar podkreśla jako główny argument motywujący realne zastosowanie spojrzenia pneumatologicznego przez Sobór na Kościół, stanowi zachowanie w centrum uwagi - Chrystusa. Utrzymana zostaje w ten sposób teologiczna równowaga, podobnie jak w obrazie św. Ireneusza, pomiędzy dwoma korelującymi ze sobą, a jednocześnie niezależnymi od siebie, misjami - Syna i Ducha Świętego. W wizji Congara Syn Boży jest tworzacym (instituant) Kościół, a Duch Święty występuje jako wspót-tworzący (co-instituant) Kościół. Założycielem Kościoła jest Chrystus - Kościół staje się instytucją (społecznością). Kościół ten pozostaje jednak otwarty na działanie i Syna, i Ducha Świętego, gdyż rozumienie instytucji jest tutaj dynamiczne.

Jako trzeci wniosek tego artykułu chcę potwierdzić znaczną współzależność koncepcji eklezjologii pneumatologicznej teologii Yves'a Congara z tekstem Lumen gentium. Potwierdza to niniejsza analiza odwołująca się do klucza interpretacji przyczynku Soboru do tematu działania Ducha Świętego w Kościele: działanie Pana Boga w wymiarze „wertykalnym” i „horyzontalnym”. Pięć tez pneumatologii zaproponowanych przez Congara w jego artykule Aktualność pneumatologii z 1973 roku praktycznie w całości odnosi się do teologii zawartej w tekście Lumen gentium. Porównanie przemyśleń Congara z Konstytucją Lumen gentium pozwala stwierdzić, że Sobór nie prezentuje pneumatologicznej 
syntezy eklezjologii, ale zarazem nie zamyka się w jednym ograniczonym podejściu teologicznym w tej kwestii. Lumen gentium przedstawia miejscami w całości pełne opracowanie jakiegoś ważnego tematu pneumatologii (np. w kwestii darów i charyzmatów KK 12), a niekiedy zawiera tylko ziarna pewnych fundamentalnych przemyśleń związanych z eklezjologią pneumatologiczną Congara (np. subtelność Ducha Świętego, jego funkcja aktualizująca dzieła Chrystusa). Niewątpliwie najważniejszym osiągnięciem Soboru była próba zrozumienia Ducha Świętego i Kościoła w wymiarze ekonomii objawienia, czyli przez tajemnicę wcielenia, otwierającą perspektywę dla teologii w wymiarze historii i eschatologii. Jest tutaj perspektywa odnowionej teologii zastosowana przez Sobór, chęć zrozumienia aktualności Kościoła i samego Boga. Tak jak podkreśla to w swoich konkluzjach badawczych Mariusz Jagielski: „[j]eśli dzieło Chrystusa nie jest tylko sprawą przeszłości Kościoła, to dzięki Duchowi Świętemu jest to jego misja w Kościele, a stąd wynika ważność pneumatologii dla zrozumienia Kościoła w jego dzisiaj" $" 72$.

Podsumowując czwarty, ostatni, wniosek tego studium, stwierdzam, że faktycznie istnieje pewne ograniczenie pneumatologicznego wyjaśnienia Kościoła, które proponuje refleksja Konstytucji dogmatycznej o Kościele Lumen gentium. Congar stwierdza, że tak jak w wielu domenach, tak również w kwestii pneumatologii, Sobór jest niedoskonały: „[1]iczne punkty widzenia są, jeśli nie kompromisami, to przynajmniej pewnymi zarysami myśli, które zostały sformułowane w połowie drogi"’3. $\mathrm{Z}$ jednej strony posoborowe wyjaśnienia Congara słusznie odrzuciły zarzuty krytyków o całkowitym braku pneumatologii w tekstach soborowych. Z drugiej jednak Congar miał cały czas świadomość, że wypracowana teologia Soboru w tej kwestii była tylko pewnym niezakończonym etapem formułowania eklezjologii odnoszącej się do pneumatologii. Co więcej, jego własne uzyskane odpowiedzi badawcze, próbujące stworzyć eklezjologię pneumatologiczną, uświadomiły mu, że mają mankament zbytniego skoncentrowania na samej eklezjologii. Pneumatologia oparta na poszukiwaniu wymiaru ekonomii w eklezjologii zredukowała bowiem wymiar ekonomii w chrystologii. Na przełomie lat siedemdziesiątych i osiemdziesiątych teolog ten podjął się nawet transformacji swojego podejścia teologicznego. Chcąc przekroczyć ograniczenia teologiczne, postanowił sformułować uzupełniający wykład w tej kwestii. Zamiast dalszego rozwijania eklezjologii pneumatologicznej, której synteza okazała się ostatecznie niemożliwa, teolog zaczął poszerzać swoje badania wokół chrystologii pneumatologicznej. Rozpoczęła się nowa i długa przygoda badawcza.

72 „Si l'œuvre du Christ n'est pas uniquement dans le passé de l'Église c'est par l'Esprit-Saint, c'est sa mission dans l'Église, d'où l'importance de la pneumatologie pour l'intelligibilité de l'Église dans son aujourd'hui". M. Jagielski. L'Église..., s. 366.

73 „Beaucoup de ses vues sont, sinon des compromis, du moins des ébauches et se tiennent, en quelque sorte, à mi-chemin”. Y. Congar, Les implications..., (TH, n 71), s. 176. 


\section{Pneumatology in the Ecclesiology of the Second Vatican Council's Constitution Lumen Gentium from the Perspective of Yves Congar's Theology}

\section{Summary}

For all readers of the text of the Lumen Gentium constitution of the Second Vatican Council during this event, and also immediately afterwards, it seemed that the document focused solely on the explanation of the Church from the perspective of Christ. Some of the conciliar observers, especially the Orthodox theologians, brought up criticism that the reflection of the Council was marked by a Christomonism. This study presents the question of the pneumatological implications of the ecclesiology contained in the Lumen Gentium constitution from the perspective of Yves Congar's theological thought. As the analysis of the undertaken research will show, the answer of the French theologian not only provides an essential response to the objection of Christomonism based on a direct commitment of this theologian to the co-writing of Lumen Gentium as early as March 1963, but it also gives a thorough insight into the subject-matter referring to his theological achievements already before and mainly after the Council. The Dogmatic Constitution on the Church has a distinct pneumatological dimension. The theology contained therein is related to all the theses on the subject as they were formulated by Yves Congar in 1973.

\section{Keywords}

Vatican Council II, Lumen Gentium, Yves Congar, pneumatological ecclesiology, People of God, Christomonism

\section{Słowa kluczowe}

Sobór Watykański II, Lumen gentium, Yves Congar, eklezjologia pneumatologiczna, lud Boży, chrystomonizm

\section{Skróty zastosowane w artykule}

CFi

DA

DB

$\mathrm{DE}$

DFK

- Acta Synodalia Sacrosancti Concilii Oecumenici Vaticani II, Typis Polyglottis Vaticanis, vol. I-VI (Vol. V: Processus verbales; Vol. VI: Acta secretariae generalis; Indices; Appendix; Appendix altera), 1971-1991

$\mathrm{DM}$ — „Cogitatio Fidei”

- Dekret o apostolstwie świeckich

— Dekret o pasterskich zadaniach biskupów w Kościele

- Dekret o ekumenizmie

DP

- Dekret o formacji kapłanów

FConc Suenens

- Dekret o misyjnej działalności Kościoła

- Dekret o posłudze i życiu prezbiterów

- DECLERCK L., LOUCHEZ E., Inventaire des Papiers Suenens conciliaires $d u$ cardinal L.J. Suenens, Louvain-la-Neuve, Publications de la Faculté de Théologie Louvain-la-Neuve, coll. „CahRTL”, 31 (1998) oraz DECLERCK L., Inventaire des Papiers conciliaires du cardinal L.J. Suenens. Addenda, [bmw.] 1999 
KK - Konstytucja dogmatyczna o Kościele

KL - Konstytucja o liturgii świętej

KO - Konstytucja dogmatyczna o Objawieniu Bożym

KPK - Kodeks Prawa Kanonicznego

TH - „Théologie Historique”

UnSa - „Unam Sanctam”

\section{Bibliografia}

Alberigo G., Institutions exprimant la communion entre l'episcopat universel et l'évêque de Rome [w:] Les Églises après Vatican II. Dynamisme et prospective. Actes du Colloque international de Bologne - 1980, éd. tenże, Paris 1981, s. 259-289.

Chéno R., Le Père Congar, découvreur de sources nouvelles [w:] Y. Congar, La Parole et le Souffle, Paris 2010, s. 211-221.

Chenu M.D., Theoría et praxis en théología, „Ciencia Tomista” 99 (1972), s. 3-10.

Congar Y., Actualité d'une penumatologie, „Proche-Orient” 23 (1973), s. 121-132.

Congar Y., Aktualność pneumatologii [w:] tenże, Wezwani do życia, thum. A. Ziernicki, Kraków 1999, s. 79-96.

Congar Y., Chrétiens désunis. Principes d'un «مecuménisme» catholique, (UnSa, n 1), Paris 1937.

Congar Y., De la communion des Églises à une ecclésiologie de l'Église universelle [w:] L'Épiscopat et l'Église universelle, dir. tenże, B.D. Dupuy, (UnSa), Paris 1964, s. 227-260.

Congar Y., Duch człowieka, Duch Boga, tłum. A. Foltyńska, Warszawa 1996.

Congar Y., D'une «ecclésiologie en gestation» à Lumen Gentium (Chap. I et II) [w:] tenże, Le Concile de Vatican II. Son Église. Peuple de Dieu et Corps du Christ, (TH, n 71), Paris 1984, s. $123-136$.

Congar Y., Jean Puyo interroge le père Congar. «Une vie pour la vérité», Paris 1975.

Congar Y., Je crois en l'Esprit Saint, 1: L'Esprit Saint dans l',,économie”: révélation et expérience de l'Esprit, Paris 1979.

Congar Y., Je crois en l'Esprit Saint, 2: „Il est Seigneur et Il donne la vie”, Paris 1979.

Congar Y., Je crois en l'Esprit Saint, 3: Le Fleuve de Vie (Ap 22,1) coule en Orient et en Occident, Paris 1985

Congar Y., Kościół jaki kocham, tłum. A. Ziernicki, Kraków 1997.

Congar Y., La Parole et le Souffle, (Jésus et Jésus-Christ, n²0), dir. J. Doré, nouvelle éd. rel. R. Chéno, Paris 2010.

Congar Y., La Tradition et la vie de l'Église, (Traditions chrétiennes), Paris 19842.

Congar Y., Les implications christologiques et pneumatologiques de l'ecclésiologie de Vatican II. [w:] Les Églises après Vatican II. Dynamisme et prospective. Actes du Colloque international de Bologne - 1980, éd. G. Alberigo, (TH, n 61), Paris 1982, s. 117-130 = Congar Y., Les implications christologiques et pneumatologiques de l'ecclésiologie de Vatican II [w:] tenże, Le Concile de Vatican II. Son Église. Peuple de Dieu et Corps du Christ, (TH, n 71), Paris 1984, s. 163-176.

Congar Y., L'Esprit co-instituant de l'Église. Les charismes principes structurants de l'Église? [w:] tenże, La Parole et le Souffle, Paris 2010, s. 125-135.

Congar Y., L'Esprit saint dans l'Église, „Lumière et Vie” 10 (1953), s. 51-74. 
Congar Y., Lumen Gentium n 7, L'Église, Corps Mystique du Christ vu au terme de huit siècles d'histoire de la théologie du Corps mystique [w:] tenże, Le Concile de Vatican II. Son Église. Peuple de Dieu et Corps du Christ, (TH n ${ }^{\circ}$ 71), Paris 1984, s. 137-161.

Congar Y., Pneumatologie ou «Christomonisme» dans la tradition latine? [w:] Ecclesia a Spiritu Sancto edocta. Mélanges théologiques. Hommages à Mgr Gérard Philips, (Bibliotheca Ephemeridum theologicarum Lovaniensium XXVII), J. Duculot, Gembloux 1970, s. 41-63.

Congar Y., Veux pour le concile. Enquête parmi les chrétiens, I: Catholique. Yves M.J. Congar, o.p., ,Esprit” 301 (1961), s. 691-700.

Congar Y.: Wierzę w Ducha Świętego, t. I: Objawienie i doświadczenie Ducha, thum. A. Paygert, Warszawa 1997.

Congar Y., Wierzę w Ducha Świętego, t. II: „Panem jest Duch i daje życie” (2 Kor 3,17), thum. L. Rutkowska, Warszawa 1995.

Congar Y.: Wierzę w Ducha Świętego, t. III: Rzeka życia płynie na Wschodzie i na Zachodzie (Ap 22,1), thum. L. Rutkowska, Warszawa 1996.

Congar Y., Życie dla prawdy. Jean Puyo rozmawia z ojcem Y. Congarem, thum. A. Paygert, Warszawa 1975.

Doré J., Le Père Congar, découvreur de sources nouvelles [w:] Y. Congar, La Parole et le Souffle, Paris 2010, s. 211-221.

Duvigneau P., „Supplement Vie Spirituelle”, février 1937.

Grootaers J., Peuple de Dieu [w:] Catholicisme. Hier. Aujourdhui. Demain, encyclopédie publiée par G. Mathon, G.H. Baudry, P. Guilluy, E. Thiery, t. 49: V «Perpignan-Pie V», Paris 1986, s. 97-121.

Groppe E.T., Yves Congar's theology of the Holy Spirit, Oxford-New York 2004.

Humann F.M., La relation de l'Esprit au Christ: Une relecture d'Yves Congar, (CFi), Paris 2010.

Jagielski M., L'Église dans le temps. Yves Congar: la quête d'un réalisme ecclésiologique, Paris 2015.

Küng H., The charismatic structure of the Church, „The Catholic World” august (1965), s. 302-321. Legrand H., Enjeux théologiques de la revalorisation des Églises locales et de l'Église entière, „Concilium” 71 (1972), s. 49-58.

Legrand H., La réalisation de l'Église en un lieu [w:] Initiation à la pratique de la théologie, dir. B. Lauret, F. Refoulé, t. III: Dogmatique 2, Paris 1993, s. 143-344.

Legrand H., Les évêques, les Églises locales et l'Église entière [w:] Le ministère des évêques au concile Vatican II et depuis, dir. H. Legrand, Ch. Theobald, Paris 2001, s. 201-260.

Lubac H. de, Les Églises particlières dans l'Église universelle, (Intelligence de la foi), Paris 1971.

Milciades F.R., La eclesiologia pneumatologica de Yves Congar en los escritos del periodo post-conciliar, Roma 2013.

Nissiotis N.A., Is the Vatican Council Really Ecumenical?, „The Ecumenical Review” 16 (07/1964) 4, s. 357-377.

Nissiotis N.A., Report on the Second Vatican Council, „The Ecumenical Review” 18 (04/1966) 2, s. $190-206$.

Nissiotis N.A., The Main Ecclesiological Problem of the Second Vatican Council and the Position of the Non-Roman Churches Facing It, ,Journal of Ecumenical Studies” 2 (01/1965) 1, s. 31-62.

Philips G., Schelkens K., Carnets conciliaires de Mgr Gérard Philips secrétaire adjoint de la Commission doctrinale, (Instrumenta Theologica 29), Leuven 2006. 
Pius XII, Encyklika o Mistycznym Ciele Jezusa Chrystusa. Mystici Corporis Christi, thum. A. Żychliński, Kielce 1945.

Pneumatologie orthodoxe [w:] Le Saint-Esprit, ouvr. Collectif sous la dir. de F.J. Lennhardt, P. Reymond, P. Fraenkel, (Labor et fides), Genève 1963.

Rigal J., Ecclésiologie de la communion. Son évolution historique et ses fondements, (CFi), Paris 2000.

Rigal J., Le Christ et l'Esprit fondement de l'Église, „Prêtres Diocésains” 1366 (1999), s. 181-197.

Sobór Watykański II. Konstytucje, dekrety, deklaracje, Pallottinum, Poznań 2002.

Suenens L.J., Souvenirs et Espérances, Paris 1991.

Tomasz z Akwinu św., Suma Teologiczna w skrócie, Warszawa 2000.

Vatican II, des images, des témoins. Le Cardinal Etchegaray, Mgr Gilson et le Père Cancouët racontent le Concile Vatican II, film réalisé par V. Beaulieu-Mathivet, CFRT, Paris 2006. 